\title{
The Power of Using Novel Nanopore Sequencing Technology for Diagnosis, Genomic and Pathological Studies of Covid-19
}

\section{El poder del uso de la nueva tecnología de secuenciación por nanoporos para el diagnóstico y los estudios genómicos y patológicos de Covid-19}

\author{
DOI: $10.46932 / \mathrm{sfjdv2n3-017}$
}

Received in: May 1st, 2021

Accepted in: Jun 30th, 2021

\author{
Chenghao Du \\ Bachelor degree in Cell \& Molecular biology, and Psychology. \\ Institution: University of California, San Diego \\ Address: University of California, San Diego, 9500 Gilman Dr, La Jolla, Ca 92093 \\ E-mail: chdu@ucsd.edu
}

\begin{abstract}
The novel coronavirus disease 2019 (COVID-19), originally identified in December 2019 Wuhan, China, has propagated to worldwide pandemic, causing many cases of death and morbidity. Since the development of COVID-19 vaccines is still under experimental stages without public access, different types of testing and detection ensuring rapid and accurate results are urgently required to prevent delaying isolation of infected patients. The traditional diagnostic and analytical methods of COVID-19 relied heavily on nucleic acid and antibody-antigen methods but are subject to assembly bias, restricted by reading length, showed some false positive/negative results and had a long turnaround time. Hence, three styles of nanopore sequencing techniques as complementary tools for COVID-19 diagnosis and analysis are introduced. The long-read nanopore sequencing technology has been adopted in metagenomic and pathological studies of virosphere including SARS-CoV-2 recently by either metagenomically, directly or indirectly sequencing the viral genomic RNA of SARS-CoV-2 in real-time to detect infected specimens for early isolation and treatment, to investigate the transmission and evolutionary routes of SARS-CoV-2 as well as its pathogenicity and epidemiology. In this article, the Nanopore-Based Metagenomic Sequencing, Direct RNA Nanopore Sequencing (DRS), and Nanopore Targeted Sequencing (NTS) become the main focus of the novel COVID-19 detecting analytical methods in sequencing platforms, which are discussed in comparison with other traditional and popular diagnostic methods. Finally, different types of nanopore sequencing platforms that are developed by Oxford Nanopore Technologies (ONT) due to various purposes and demands in viral genomic research are briefly discussed.
\end{abstract}

\section{RESUMEN}

La nueva enfermedad por coronavirus 2019 (COVID-19), identificada originalmente en diciembre de 2019 en Wuhan, China, se ha propagado hasta convertirse en una pandemia mundial, causando muchos casos de muerte y morbilidad. Dado que el desarrollo de las vacunas contra el COVID-19 está todavía en fase experimental sin acceso público, se necesitan urgentemente diferentes tipos de pruebas y de detección que garanticen resultados rápidos y precisos para evitar que se retrase el aislamiento de los pacientes infectados. Los métodos tradicionales de diagnóstico y análisis de COVID-19 se basaban en gran medida en los métodos de ácido nucleico y anticuerpo-antígeno, pero están sujetos a un sesgo de ensamblaje, están restringidos por la longitud de la lectura, muestran algunos resultados falsos positivos/negativos y tienen un largo tiempo de respuesta. Por lo tanto, se introducen tres estilos de técnicas de secuenciación de nanoporos como herramientas complementarias para el diagnóstico y análisis de COVID-19. La tecnología de secuenciación de nanoporos de lectura larga ha sido adoptada en estudios metagenómicos 
y patológicos de la virósfera, incluyendo el SARS-CoV-2, recientemente, mediante la secuenciación metagenómica, directa o indirecta del ARN genómico viral del SARS-CoV-2 en tiempo real para detectar especímenes infectados para su aislamiento y tratamiento tempranos, para investigar la transmisión y las rutas evolutivas del SARS-CoV-2, así como su patogenicidad y epidemiología. En este artículo, la secuenciación metagenómica basada en nanoporos, la secuenciación directa de ARN con nanoporos (DRS) y la secuenciación dirigida con nanoporos (NTS) se convierten en el foco principal de los nuevos métodos analíticos de detección de COVID-19 en plataformas de secuenciación, que se discuten en comparación con otros métodos de diagnóstico tradicionales y populares. Finalmente, se discuten brevemente los diferentes tipos de plataformas de secuenciación por nanoporos que son desarrolladas por Oxford Nanopore Technologies (ONT) debido a varios propósitos y demandas en la investigación genómica viral.

\section{INTRODUCTION}

The global outbreak of COVID-19 pandemic has resulted in many infections and mortality, and the infected population is still multiplying. The diagnosis of COVID-19 relies heavily on nucleic acid testing, antibody-antigen test, and RT-PCR sequencing test, but the current suggested methods that are subject to assembly bias and restricted by reading length also showed some rate of false negative/positive results, had long turnaround time, and failed to identify other respiratory diseases simultaneously. The drawbacks of current detecting methods lead to misdiagnosis of patients and hinder the containment of the COVID-19 pandemics to some extent. With the advantages of long-read, real-time nanopore sequencing of target amplification regions in the viral genome, the development of nanopore targeted sequencing (NTS) was able to simultaneously detect SARS-CoV-2 and other respiratory viruses with high sensitivity in a short turnaround time of 6 to10 hours using a limited amount of viral RNA samples, albeit that the detection limit was 10 standard plasmid copies per reaction [1]. NTS is approximately $100 \%$ specific to SARS-CoV-2, and the diagnostic results revealed that NTS could identify more infected patients as real positive with high consensus [1]. Furthermore, the long-read, nanopore-based Metagenomic sequencing has been used to conduct a metagenomic and pathological analysis of coronavirus in real-time by mapping out the full-length genomic sequence corresponding to its original viral genome for subsequent analysis and diagnosis. The whole and partial genome data are stored in the public Genbank available for research teams around the world. The real-time Direct RNA Nanopore Sequencing (DRS) was developed to directly sequence the full-length genomic RNA and transcriptomes of coronavirus and other viruses for viral identification at high resolution and accuracy without prior assembly bias [2]. That is, it preserves RNA modification that cleverly avoids the drawbacks of other sequencing methods contained, including reverse transcription(cDNA) and restriction from amplified RNA fragments of material input [3]. In addition to the performance of DRS, all three nanopore sequencing methods together are capable of effectively monitoring the mutation \& recombination of viral 
genome, analyzing the transmission routes, classifying different strains of SARS-CoV-2 virus, and crossdetecting other respiratory viruses in the infected specimens. Therefore, Nanopore sequencing is not only an applicable and suitable COVID-19 detecting technique in both clinical context and controlled-lab environment, but also provides extended features to study the pathogenicity and epidemiology of SARSCoV-2 to effectively control and comprehend the pandemic.

Coronaviruses are the family of plus single-stranded RNA (+ssRNA) viruses with the spike glycoprotein responsible for the binding of host cell receptors and subsequent entrance that are consist of four genera: alphacoronavirus, betacoronavirus, gammacoronavirus, and deltacoronavirus [4]. The SARS-CoV-2 identified as the trigger of COVID-19 pandemic belongs to betacoronavirus, along with SARS-CoV and MERS-CoV [5]. The genome structure of SARS-CoV-2 includes four structural proteins: spike (S), membrane (M), envelope (E), and nucleocapsid (N) proteins [6]. In clinical practice, diagnosis of COVID-19 infection is achieved via viral RNA sequence detection primarily using RT-PCR as one of the NAATs.

\section{LIMITATION OF TRADITIONAL DIAGNOSTIC METHODS OF COVID-19 BEFORE NANOPORE SEQUENCING}

It is well studied nowadays that the incubation period of COVID-19 is 2-7 days [7], sometimes longer up to 14 days, without observable and obvious symptoms. During this period, the virus can spread from infected or no-symptom infected carriers to uninfected populations. Therefore, isolation of infected patients and precise diagnosis of COVID-19 as soon as possible plays an important role in controlling the pandemic of COVID-19. Antibody antigen-based detection methods are fast, but they are susceptible to factors ranging from the presence of fibrin, sample hemolysis, bacterial contamination, to patient's autoantibodies, leading to a high rate of false positive. As a result, nucleic acid detection is prioritized to be the top standard for COVID-19 diagnosis, and several methods, including RT-PCR sequencing, are adopted to detect SARS-CoV-2 that causes COVID-19 [8]. In particular, real-time reverse transcription polymerase chain reaction (RT-qPCR) is currently the most prevalent diagnostic method to detect SARSCoV-2, because RT-qPCR has high specificity, is relatively economical and efficient that can generate results for numerous patients simultaneously in less than 2 days. However, it fails to accurately assess and analyze nucleic acid sequences of amplified gene fragments with long reading length. Based on the guidelines from PCR manufactures, a positive SARS-CoV-2 infection can be confirmed by monitoring one or two gene sites from viral genomic RNA, such as Spike (S) gene from 21,563 to 25,384 and Nucleocapsid (N) gene around 28,274-29,533 [9]. In addition, RT-qPCR potentially demonstrates a relatively high false-negative rate in clinical settings that promotes the spread of infection by delaying 
isolation of patients and thus cannot receive immediate treatment, causing more transmission of COVID19 [10].

\section{NANOPORE SEQUENCING TECHNOLOGY}

\subsection{SEQUENCING PLATFORMS}

Sequencing techniques that are widely used nowadays in academic research and clinical diagnosis for pathogen identification and genomic surveillance of virus evolution [17] provide another popular platform for detecting the presence (or absence) of various virus families, including SARS-CoV-2 [18]. The traditional short-read massively parallel sequencing platform-Next-generation sequencing (NGS) that are able to generate many million copies of short-reads in parallel, sequenced types of nucleic acids via receiving the chemical or light signals emitted as nucleotides are complimentarily base paired with the oligo DNA templates. For instance, the most widely applied Next-generation sequencing Illumina has a synthesis model that requires multiple alternating cycles. It takes less than minutes to complete each cycle and decode the optical signals generated by adding a single complementary nucleotide to each DNA fragment repeatedly. Depending on the length of bp readouts and data processing, the full sequencing process requires 1 to 3 days to produce a high sample volume of detection, which may not be considered as the optimal detection duration in clinical usage. Noted that until the entire genome sequencing process ends, the data obtained from sequencing platforms cannot be examined further. The traditional short-read massive parallel next-generation sequencing methods, including Pyrosequencing, Ion Torrent semiconductor, and Illumina, are restricted by the read length to 200-400 nucleotides [19]. To illustrate, the short-read sequencing of highly fragmented viral RNAs greatly complicates the research of SARSCoV-2 that potentially has a large family of similar homologous genomes sharing similar inheritance patterns $[20,21]$. Since the mRNA of coronavirus are practically inherited identically from the homologous genome sequence of original coronavirus strains, short-read output usually is challenging assigned to specific sgRNA viruses clearly. Therefore, the real-time long-read nanopore sequencing becomes the best candidate to monitor the viral genome mutation and recombination of SARS-CoV-2 by performing full-length genomic sequence analysis.

\subsection{NANOPORE SEQUENCING METHODS}

Different types of nanopore sequencing technology follow the same principle of sequencing and detection. While the SARS-CoV-2 single strand (+)RNA translocate over a designed nanopore protein, the fluctuation in currents due to the resistant property of its RNA molecules are directly detected by nanopore in real-time (refers to Figure 1.). The nanopore protein, which is comprised of two units, enzyme 
motor, and nanopore reader, incorporated among an electrically resistant membrane, divides the environment of electrolyte solution into two compartments [22]. Since the electrolyte in the solution is equally distributed, all the potential differences are concentrated inside and close to nanopore protein. It indicates that the negatively charged SARS-CoV-2 RNA molecules in the electrolytes will only be impacted by different forces from the electric field and surrounding close to the nanopore capturing region [23]. The enzyme motor specifically controls and stabilizes the translocation of SARS-CoV-2 RNA single strand (also does unwinding if dsDNA translocate). Once entering the nanopore, the SARS-CoV-2 ssRNA passes through the pore with a combination of electrophoretic, electroosmotic and thermophoretic forces [24]. Meanwhile, the translocation process of SARS-CoV-2 ssRNA occupies a certain amount of volume that partially restrain and resist the flow of ions in the nanopore reader, thereby sensing continuous sharp current drops by nanopore reader based on different length and NTS passing through. The electrical signal is then decoded to generate a specific DNA/RNA sequence correspondingly. As a sequence fragment passing through has been fully decoded, enzyme motor is detached, waiting for the loading of a new SARS-CoV-2 RNA strand. The fluctuation of electrical signal, current drops, in respect to different nucleotides translocating through nanopore proteins are recorded in real-time and used immediately for subsequent sequence analysis [25]. The SARS-CoV-2 ssRNA translocate across nanopores at astonishingly high speed, about 450 bases per second for DNA and 80 bases per second for RNA. Nanopore sequencing is not limited by the reading length of viral RNA sequence but is restricted only by the specific amplified RNA fragments of the input material [26].

Figure 1. The side-view demonstration of how nanopore sequencing works. dsDNA and ssRNA of viral genome follow the same principle for translocating through nanopore protein except unwinding motor enzyme doesn't separate single-strand RNA. Nanopore detects and monitors the fluctuation to an electrical current as a DNA/RNA sequence is moved across a protein nanopore.

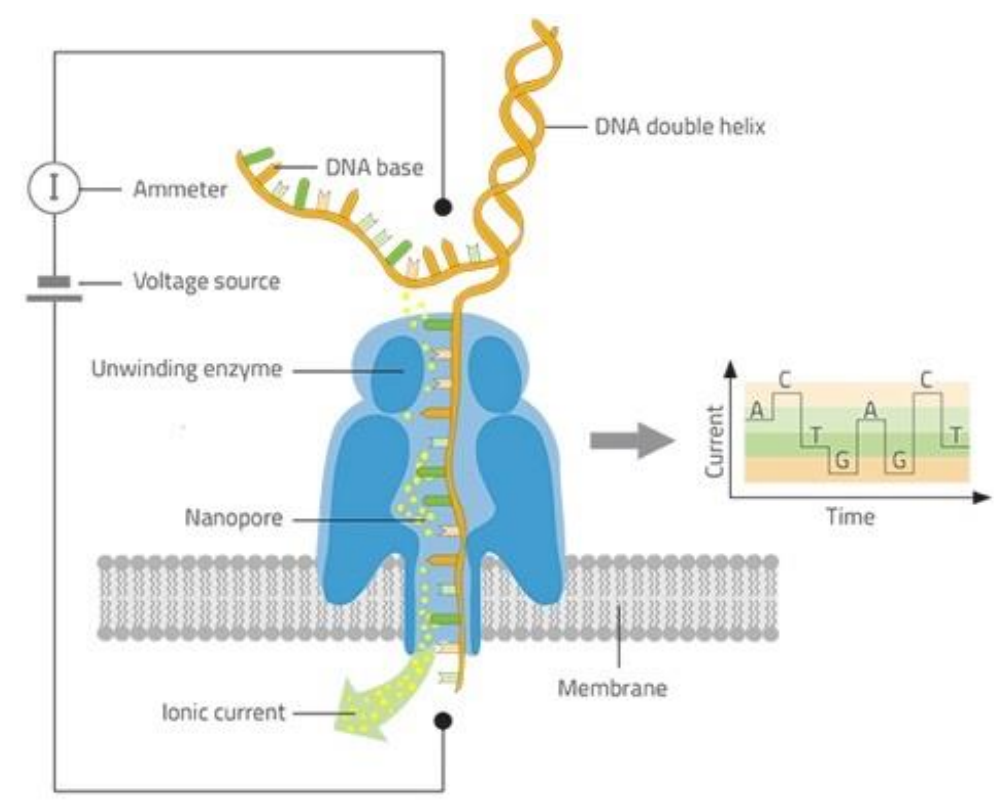




\subsubsection{Nanopore-based Metagenomic Sequencing}

Before the COVID-19 pandemic, nanopore sequencing has been adopted in metagenomic studies of virosphere [27] and researches focusing on transmission routes [28, 29]. In the clinical setting, it has also been proved that the methods of nanoporous metagenomic sequencing are promising to effectively detect the infections of respiratory virus and bacteria from affected patients [30]. The bacteria containing antibiotic resistance genes and pathogens can be determined within a few hours. Unlike traditional cultivation techniques, the efficiency and efficacy of real-time generation of nanopore sequencer are far outweighed other methods. By contrary, nanopore-based Metagenomic sequencing was used to identify potential pathogens involved in the diagnosis of the COVID-19 [31]. It also can perform the routinely sampling on a certain amount of clinical specimens infected by SARS-CoV-2 to facilitate rapid genomic surveillance of SARS-CoV-2, comprehensively understanding its evolutionary pathway, transmission and pathogenicity [31,32]. Numerous popular sequencing protocols based on next-generation sequencing (NGS) and full-length nanopore sequencing are being used to rapidly identify the genomic and transcriptomic sequences of SARS-CoV-2 [33-35]. For instance, Lu's team harnessed a combination of Sanger, Illumina, and Oxford nanopore MinION sequencing technologies to generate the metagenomic sequences of SARS-CoV-2 from six clinical samples in China [33]. In the United States, Holshue's team reported the first case of the COVID-19. Similarly, with the combination of the Sanger, Illumina, and MinION nanopore methods, they also sequenced the metagenome of SARS-CoV-2 RNA to monitor the entry routes of virus and possible evolutionary changes in US [34]. Taking advantage of MinION nanopore technology for metagenome sequencing combined with phylogenetic analyses offered a precious platform to identify the virus and investigate the entering routes of SARS-CoV-2 when it first emerged in Brazil, Latin America [35]. By 12/07/2020, there are more than 112,615 sequence reading archives and 43,779 Nucleotide records submitted and stored in Genbank. Checking the Genbank at [https://www.ncbi.nlm.nih.gov/genbank/sars-cov-2-seqs/] includes many full-length and partial sequences of SARS-CoV-2 from research teams all over the world.

\subsubsection{Direct RNA Nanopore Sequencing (DRS)}

To characterize the viral RNAs of coronavirus, nanopore sequencing are also applied to directly sequence the transcriptome of coronavirus and the full-length genomic RNA of coronavirus, called Direct RNA nanopore sequencing (DRS) [36]. To be more specific regarding to the DRS technique, many studies have been revealed that the sequence analyses of RNA virus genomes and transcriptomes remain challenging because of the exceptional genetic elasticity and variability of these viruses, including SARSCoV-2. Similar to many other $(+)$ ssRNA viruses, SARS-CoV-2 exhibits high rates of gene recombination 
and reassortment [37]. Due to the high rate of virulence mutation and gene reassortment, genome replication by viral RNA-dependent RNA polymerases causes more strains of closely-associated viruses, known as "quasispecies." [2] Traditional short-read sequencing techniques are not well-suited for reconstructing large volume of full-length haplotypes (inherited identical original genome) of RNA virus genomes firstly, and sgRNAs composed of noncontiguous genome regions secondly [2]. Previously, viral transcriptomes were studied with nanopore sequencing of cDNA that is reversely transcribed from mRNA templates [38], but the results are subject to the bias from reverse transcription and amplification. Hence, the long-read, nanopore-based direct RNA sequencing (DRS) method, as developed by ONT can be used in real-time to analyze and detect viral RNAs replicated in cells infected by the coronavirus, while consistent RNA modifications in coronavirus can be preserved and detected using nanopore DRS. As the improvement, DRS avoids some drawbacks of traditional sequencing methods, especially the cDNA reverse transcription that might artificially generate an RNA-RNA chimera to complicate the differentiation from naturally occurring version [39], and restriction from amplified fragments of the input material. With the DRS technique, Adrian's team has directly mapped the longest contiguous read about $26-\mathrm{kb}$ to the viral reference genome of SARS-CoV-2. By combining Illumina and Oxford Nanopore sequencing with MinION sequencer, they also reconstructed a highly accurate consensus sequence of the human coronavirus (HCoV)-229E genome about $27.3 \mathrm{~kb}$ [39]. The DRS techniques have been proved effective for viral analysis in many studies that used DRS to investigate the transcriptome of DNA viruses HSV [40] and sequence the original genome of Influenza A virus (Keller et al. 2018), thus indicating that DRS is also a reliable and suitable method to study SARS-CoV-2 potentially. These studies exhibited an intricate arrangement and complexity of viral genome with preserved RNA modifications [41] and lay a strong foundation for the future analysis of viral evolutionary path as well as the mutation rate of coronavirus. However, the abundance of viral RNAs is relatively in limited proportion compared with host viral RNAs of SARS-CoV-2 extracted from clinical samples. According to the nanopore-based metagenomic sequencing and Direct RNA nanopore sequencing methods, a large amount of alignment data is used that compensate for the limited viral RNA samples to generate unbiased sequence analysis of viruses genome and human nucleic acids, resulting in substantial related costs of money and timeconsuming analysis to complete eventually. For this reason, the recent studies used a more advanced technique ARTIC method with multiplex PCR to research the Zika and Ebola [42], and sequence the whole genome of SARS-CoV-2 from virus extracts and clinical specimens [43] by evaluating the overlapping region between multiplex amplicons. The ARTIC method allowed scientists to further monitor the pathogenicity, the key mutation in the viral genome overtime that causes potential evolution, and to track down its transmission patterns [44]. However, since huge demands of clinical samples are 
waiting to be tested as the ongoing COVID-19 pandemic worsening that are required for a short turnaround time, some of these nanopore-based sequencings are partially ill-suited for clinical diagnose and detection of SARS-CoV-2 outside of the laboratory. We need an extra nanopore sequencing technique that has an even shorter turnaround time and cross-detect various respiratory viruses.

\subsubsection{Nanopore Targeted Sequencing (NTS)}

In the next part of this article, we want to highlight the foundation, development, and future expectation of Nanopore Targeted Sequencing (NTS). Nanopore sequencing technology dominated by Oxford Nanopore Technologies (ONT) are relatively new approaches in the sequencing market and application compare with other sequencing platforms. Since the emergence of COVID-19 in China, many research teams from all over the world were wholeheartedly devoted to academic research related to diagnosis, detection methods, genomic \& transcriptome sequencing of SARS-CoV-2 for subsequent analysis and pathogenicity studying, and more importantly, developing effective vaccine treatment to save as many lives as possible. For the diagnosis and deep research of SARS-CoV-2, Wang's team is dedicated to the development of the Nanopore Targeted Sequencing (NTS) platform that possesses the advantages of targeted amplification and long-read nanopore sequencing in real-time with high sensitivity in less than 6-10 hours since January 2020 [1]. Simultaneously, NTS is able to detect other respiratory viruses such as adenovirus, rhinovirus, and influenza with SARS-CoV-2 together (overlapping symptoms include fever, short breadth, even pneumonia), monitoring mutated viral genome at different RNA sites like ORF1a $\mathrm{b}$ and $\mathrm{N}$ genes, classifying the family of SARS-CoV-2. Cross infection by more than one respiratory virus is extremely dangerous to patients during the COVID-19 pandemics as the symptoms may overlap. The coronavirus testing is also prioritized, causing more false diagnostic results and ignoring other lethal respiratory viruses' clinical diagnosis for effective treatment. In fact, the majority of the current detection methods are using the whole-genome sequencing platform to perform thousands of tests every day, which are not that cost-effective and relatively time-consuming with low throughput. However, the data from these intensive tests can hardly be harnessed to investigate virulence mutations, evolution, epidemiology, and pathogenicity of SARS-CoV-2. Hence, Wang's team conducted clinical diagnostic tests with NTS at the beginning of February [1] to inform clinical treatment about cross-infection and pave the way for research teams to further study SARS-CoV-2 effectively, emphasizing the importance of cross-infection detection and pandemic control. Many studies exhibited that multiplex amplicon sequencing is time-saving and more sensitive to the low-copy small amount of viral RNA in comparison with nanoporous metagenomic sequencing and DRS [45-47]. Therefore, knowing the property of multiplex amplicon, the design of NTS is based on the amplicon of 11 viral gene fragments and the 
specific sites of ORF1a, ORF1b (refers to Figure 2.) for amplification found in SARS-CoV-2 using designed primers, followed by sequencing of the targeted amplicons on the nanopore sequencing platform. For sequencing, the targeted amplicons of viral gene sites in SARS-CoV-2 genome, the optimal nanopore platform that has the capability to sequence long-read gene fragments and decodes the sequencing data output in real-time is considered as the better candidate [47]. Thus, the SARS-CoV-2 infection can be rapidly confirmed with this platform of sequencing targeted amplification sites by frequently mapping out the viral genome sequence of SARS-CoV-2, determining the identity of the output sequence, read numbers, and coverage [1]. The full turnaround time of NTS can be maintained at 6-10 hours regarding the NTS method, which is an acceptable time for clinical application. The identical barcode was attached to two ends of the PCR product from the same SARS-CoV-2 infected sample using a barcoding PCR step, after the amplification with multiplex PCR of viral cDNA is reversely transcribed from total (+)ssRNA of SARS-CoV-2. Subsequently, the barcoded PCR product was selected and combined for the preparation of sequencing library. It is worth to emphasize that by using commercial kits to directly ligate barcodes to multiplex PCR products during sequencing library preparation, the barcoded PCR step can be eliminated to further reduce full turnaround time (6-10h) and risk of cross-contamination [1]. Finally, this NTS platform that can generate long precise nucleic acids allows for determination if viral RNAs were experiencing gene reassortment or random mutation among transmission compared with its strain of origin. All of the advantages and characteristics of NTS summarized above will certainly lay the foundation and provide valuable data to conduct more viral and epidemiological analysis for other research teams worldwide.

Figure 2. SARS-CoV-2 viral genome structure containing important gene fragments for virus identification and diagnosis, ORF1a, ORF1b, Spike (S), Nucleocapsid (M), Membrane (M), and Envelope(E), etc. 


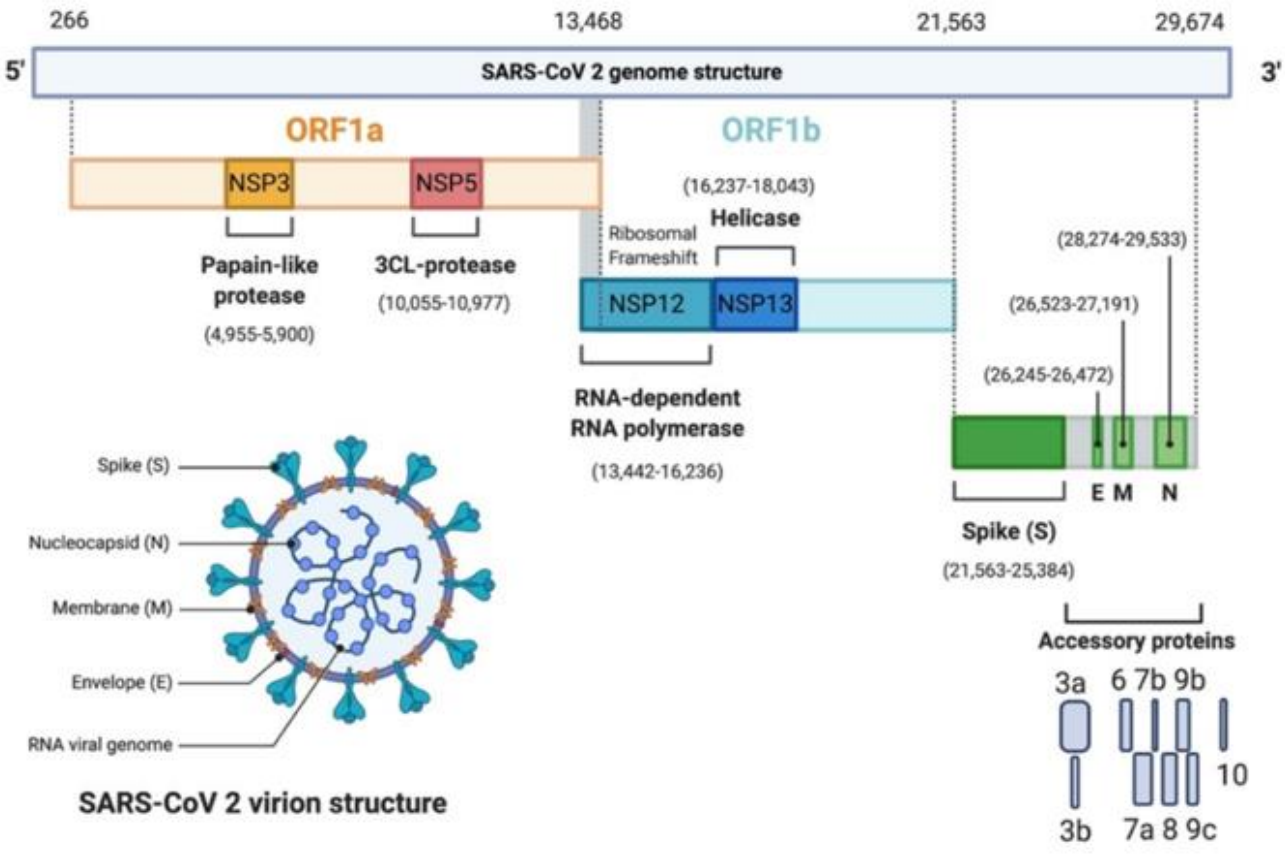

\section{NANOPORE PRODUCT FAMILY}

Figure 3. Nanopore product family: different kinds of nanopore sequencing equipment. Oxford Nanopore Technologies played a dominant role in the development of Nanopore sequencing instruments in viral genomic research [48].

\section{NANOPORE PRODUCT FAMILY \\ One core technology, real-time, on-demand}

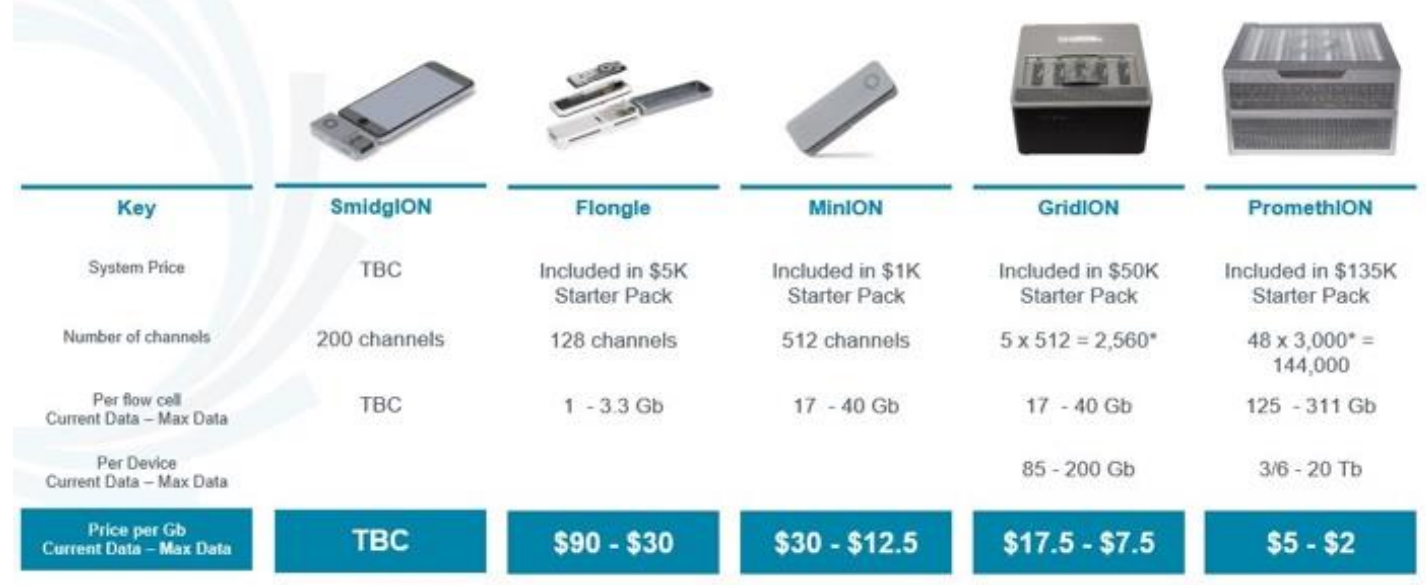

Table 1. General function and characteristics of nanopore sequencers from miniature devices to high-throughput installations [48].

\begin{tabular}{|c|c|c|c|c|c|c|}
\hline & $\begin{array}{c}\text { SmidgIO } \\
\text { N }\end{array}$ & Plongle & Fongle & MinION & GridION & $\begin{array}{c}\text { PromethIO } \\
\text { N }\end{array}$ \\
\hline $\begin{array}{c}\text { Developmen } \\
\mathrm{t}\end{array}$ & $\begin{array}{c}\text { In Early } \\
\text { developm } \\
\text { ent }\end{array}$ & $\begin{array}{c}\text { In Early } \\
\text { developme } \\
\text { nt }\end{array}$ & $\begin{array}{c}\text { Commercial } \\
\text { ized }\end{array}$ & $\begin{array}{c}\text { Commercial } \\
\text { ized }\end{array}$ & $\begin{array}{c}\text { Commercial } \\
\text { ized }\end{array}$ & $\begin{array}{c}\text { Commercial } \\
\text { ized }\end{array}$ \\
\hline Function & $\begin{array}{c}\text { Same } \\
\text { nanopore }\end{array}$ & $\begin{array}{c}\text { High- } \\
\text { throughput, } \\
\text { real-time, }\end{array}$ & $\begin{array}{c}\text { An adapter } \\
\text { for MinION } \\
\text { for smaller }\end{array}$ & $\begin{array}{c}\text { Real-time } \\
\text { analysis for } \\
\text { rapid, }\end{array}$ & $\begin{array}{c}\text { High } \\
\text { capacity }\end{array}$ & $\begin{array}{c}\text { High- } \\
\text { throughput, } \\
\text { high-sample }\end{array}$ \\
\hline
\end{tabular}




\begin{tabular}{|c|c|c|c|c|c|c|}
\hline & $\begin{array}{c}\text { sensing } \\
\text { technolog } \\
\text { y as } \\
\text { MinION } \\
\text { and } \\
\text { PromethI } \\
\text { ON. }\end{array}$ & $\begin{array}{l}\text { long-read } \\
\text { sequencing } \\
\text { for smaller } \\
\text { tests or } \\
\text { experiment } \\
\text { s. }\end{array}$ & $\begin{array}{c}\text { tests or } \\
\text { experiments } \\
\text { Single-use, } \\
\text { on-demand, } \\
\text { cost } \\
\text { efficient } \\
\text { sequencing. }\end{array}$ & $\begin{array}{c}\text { efficient } \\
\text { workflows } \\
\text { adaptable to } \\
\text { direct DNA } \\
\text { or RNA } \\
\text { sequencing } \\
\text { (DRS) }\end{array}$ & $\begin{array}{c}\text { integrated } \\
\text { compute for } \\
\text { onboard, } \\
\text { real-time } \\
\text { analysis } \\
\text { Simple, } \\
\text { preconfigure } \\
\text { d device- } \\
\text { plug in and } \\
\text { start } \\
\text { running. } \\
\text { Compatible } \\
\text { with } \\
\text { MinION } \\
\text { and Flongle } \\
\text { flow cells. }\end{array}$ & $\begin{array}{c}\text { number } \\
\text { benchtop } \\
\text { system. } \\
\text { Same } \\
\text { workflow as } \\
\text { MinION at } \\
\text { larger scale }\end{array}$ \\
\hline $\begin{array}{c}\text { Characteristi } \\
\text { cs }\end{array}$ & $\begin{array}{l}\text { Designed } \\
\text { to be the } \\
\text { smallest } \\
\text { sequencin } \\
\text { g device } \\
\text { and } \\
\text { designed } \\
\text { for use } \\
\text { with a } \\
\text { smartpho } \\
\text { ne in any } \\
\text { location. }\end{array}$ & $\begin{array}{c}\text { Cost- } \\
\text { efficient, } \\
\text { 96-well } \\
\text { plate } \\
\text { format } \\
\text { compatible } \\
\text { with high- } \\
\text { throughput } \\
\text { automation } \\
.\end{array}$ & $\begin{array}{l}\text { Suitable for } \\
\text { quality } \\
\text { checks, } \\
\text { amplicons, } \\
\text { smaller } \\
\text { genomes, } \\
\text { targeted } \\
\text { regions, or } \\
\text { those } \\
\text { interested in } \\
\text { diagnostics/ } \\
\text { other tests. }\end{array}$ & $\begin{array}{c}\text { Pocket- } \\
\text { sized, } \\
\text { portable } \\
\text { device for } \\
\text { biological } \\
\text { analysis } \\
\text { up to } 512 \\
\text { nanopore } \\
\text { channels. } \\
\text { Simple 10- } \\
\text { min sample } \\
\text { prep } \\
\text { available. }\end{array}$ & $\begin{array}{c}\text { Five } \\
\text { individually } \\
\text { addressable } \\
\text { flow cell } \\
\text { positions. } \\
\text { Generate as } \\
\text { much as } 150 \\
\text { Gb output } \\
\text { from a } \\
\text { single } \\
\text { experiment }\end{array}$ & $\begin{array}{l}\text { Modular: } \\
\text { Up to } 48 \\
\text { flow cells, } \\
\text { each with up } \\
\text { to } 3,000 \\
\text { nanopore } \\
\text { channels } \\
\text { (total up to } \\
144,000 \text { ) } \\
\text { Flow cells } \\
\text { may be run } \\
\text { individually } \\
\text { or } \\
\text { concurrently }\end{array}$ \\
\hline
\end{tabular}

\section{CONCLUSION}

The nanopore sequencing is a powerful and accurate diagnostic technique for COVID-19 pandemic, according to the discussion above, including nanopore-based metagenomic sequencing, direct RNA nanopore sequencing (DRS), and nanopore targeted sequencing (NTS). Increasing SARS-CoV-2 infected clinical specimens that are diagnosed negative or inconclusive by RT-qPCR or CRISPR-Casbased detection were identified as real positive by different types of nanopore sequencing. All three nanopore sequencing platforms enable the genomic surveillance of viral RNA mutations and recombination, transmission pathway monitoring, and categorization of SARS-CoV-2 to enrich epidemiological and pathogenetic analyses of many viruses in the future with up-to-date data. Although nanopore sequencing platforms for both clinical diagnosis and research is a novel, cutting-edge technology to study SARS-CoV-2, challenges, and difficulties related to SAR-CoV-2 detection remain unresolved using nanopore sequencing methods. The quality and detail interpretation of the nanopore sequencing data should still accept assistance from bioinformatic expertise since the available instruments are at an early stage of development. However, the potential of nanopore sequencing technology that provides new insights into different perspectives of viral replication and evolution has a promising future. 
For instance, the future study using nanopore sequencing could investigate both strands of the RNA genome and the transcriptome of coronavirus to realize a more exhaustive understanding. To fully exploit the potential of nanopore sequencing methods in the future, more improvement and nanopore-based research are highly encouraged, by first reducing the high error rate of data decoding and output currently, which is troublesome to study viruses that its genome inherited together and shared from a single parent, like SARS-CoV-2. Furthermore, the cost of material \& library preparation and turnaround time also could be reduced by applying barcode adapters and shortening the sequencing protocols of different nanopore sequencing methods, such as combining two steps together during sequencing library preparation. The shorter the sequencing protocols that still contain all the essential steps, the less turnaround time for efficient clinical diagnosis can be achieved which potentially are able to limit RNA degradation during sequencing library preparation. Indeed, the turnaround time for NTS, which requires a more skilful operation, is relatively longer than the turnaround time of RT-qPCR. Thus we recommend not only using RT-qPCR and other detection methods to compensate for the limitation of some nanopore sequencing platforms, but also having multiple nanopore sequencing methods (MNS, DRS, NTS) used cooperatively to tackle the challenges that remained in the single type. While RT-qPCR can rapidly detect the presence of SARS-CoV-2 with a high proportion of viral RNAs, followed by nanopore sequencing methods to further accurately assess and verify the detection results. Therefore, intensive research data related to nanopore sequencing detection of SARS-CoV-2 are encouraged to collect recently to optimize the accuracy of diagnostic results for immediate isolation and effectively control COVID-19 pandemics worldwide. We believe that there are no absolutely best nanopore sequencing detection methods or analytical nanopore techniques for clinical use and research per se, but relatively a better method depending on different clinical settings, demands, and requirements. 


\section{REFERENCES}

1. M. Wang, A. Fu, B. Hu, Y. Tong, R. Liu, Z. Liu, J. Gu, B. Xiang, J. Liu, W. Jiang, G. Shen, W. Zhao, D. Men, Z. Deng, L. Yu, W. Wei, Y. Li, T. Liu T, Small (Weinheim an der Bergstrasse, Germany), 16,32 (2020)

2. A. Viehweger, S. Krautwurst, K. Lamkiewicz, R. Madhugiri, J. Ziebuhr, M. Hölzer, M. Marz, Genome research, 29,9, 1545-1554 (2019)

3. AM. Smith, M. Jain, L. Mulroney. DR. Garalde, M. Akeson, PloS one, 14,5, e0216709 (2019)

4. Y. Chen, Q. Liu, D. Guo, Journal of medical virology, 92,4, 418-423 (2020)

5. X. Ou, Y. Liu, X. Lei, P. Li, D. Mi, L. Ren, L. Guo, R. Guo, T. Chen, J. Hu, Z. Xiang, Z. Mu, X. Chen, J. Chen, K. Hu, Q. Jin, J. Wang, Z. Qian, Nature communications, 11,1, 1620 (2020)

6. S. Satarker, M. Nampoothiri, Arch Med Res, Epub, 482-491 (2020)

7. W. Guan, Z. Ni, Y. Hu, The New England journal of medicine, 382,18, 1708-1720 (2020)

8. R. Liu, A. Fu, Z. Deng, Y. Li, T. Liu, VIEW, 1, e4 (2020)

9. YK. Verma, R. Verma, N. Tyagi, Stem Cell Rev and Rep (2020)

10. Y. Wang, H. Kang, X. Liu, Z. Tong, Journal of medical virology, 92,6, 538-539 (2020)

11. AA. Green, PA. Silver, JJ. Collins JJ, P. Yin. Cell, 159,4, 925-39 (2014)

12. K. Pardee, AA. Green, T. Ferrante, DE. Cameron, A. DaleyKeyser, P. Yin, JJ. Collins, Cell, 159,4, 940-54 (2014)

13. F. Zhang, https://www.broadinstitute.org/files/publications/special/COVID19\%20detection\%20(updated).pdf (Accessed: December, 2020)

14. JS. Gootenberg, O. Abudayyeh, JW. Lee, P. Essletzbichler, AJ. Dy, J. Joung, V. Verdine, N. Donghia, NM Daringer, CA. Freije, C. Myhrvold C, RP. Bhattacharyya, J. Livny, A. Regev, EV. Koonin, DT. Hung, PC. Sabeti, JJ Collins, F. Zhang, Science (New York, N.Y.), 356,6336, 438-442 (2017)

15. JP. Broughton, X. Deng, G. Yu, CL. Fasching, V. Servellita, J. Singh, X. Miao, JA. Streithorst, A. Granados, A. Sotomayor-Gonzalez, K. Zorn, A. Gopez, E. Hsu, W. Gu, S. Miller, CY. Pan, H. Guevara, DA. Wadford, JS. Chen JS, CY. Chiu, Nature biotechnology, 38,7, 870-874 (2020)

16. YC. Su, D. Anderson, BE. Young, F. Zhu, M. Linster, S. Kalimuddin, JG. Low, Z. Yan, J. Jayakumar, L. Sun, GZ. Yan, IH. Mendenhall, YS. Leo, DC. Lye, LF. Wang, GJ. Smith, bioRxiv (2020)

17. MR. Wilson, SN. Naccache, E. Samayoa, M. Biagtan, H. Bashir, G. Yu, SM. Salamat, S. Somasekar, S. Federman, S. Miller, R. Sokolic, E. Garabedian, F. Candotti, RH. Buckley, KD. Reed K, TL. Meyer, CM. Seroogy, R. Galloway, SL. Henderson, JE. Gern. JL. DeRisi, C. Chiu, The New England journal of medicine. 370,25, 2408-17 (2014) 
18. P. Zhou, X. Yang, G. Wang, B. Hu B, L. Zhang, W. Zhang, H. Si, Y. Zhu, B. Li, C, Huang, H. Chen, J. Chen, Y. Luo, H. Guo, R. Jiang, M. Liu, Y. Chen Y, X. Shen, X. Wang, X. Zheng, Nature, 579,7798, 270-273 (2020)

19. M. Hölzer, Martin, M. Manja Marz, Advances in virus research, 99, 233-257 (2017)

20. MA. Nowak, Trends in ecology \& evolution, 7,4, 118-21 (1992)

21. JA. Baaijens, A. Aabidine, E. Rivals E, A. Schönhuth, Genome research, 27,5, 835-848 (2017)

22. D. Talaga, J. Li. Genome research Journal of the American Chemical Society, 131,26, 9287-97 (2009)

23. P. Chen, J. Gu, E. Brandin, Y. Kim, Q. Wang, D. Branton, Nano letters, 4,11, 2293-2298 (2004)

24. N. Varongchayakul, J. Song, A. Meller, MW. Grinstaff, Chemical Society reviews, 47,23, 8512-8524, (2018)

25. D. Dreamer, M. Akeson, D. Branton, Nature biotechnology, 34,5, 518-24 (2016)

26. M. Jain, HE. Olsen, B. Paten, M. Akeson, Genome biology, 17,1, 239 (2016)

27. J. Warwick-Dugdale, N. Solonenko, K. Moore, L. Chittick, AC. Gregory, MJ. Allen, MB. Sullivan, B. Temperton, PeerJ, 7, e6800, 25 (2019)

28. J. Quick, NJ. Loman, S. Duraffour, JT. Simpson et al, Nature, 530,7589 (2016)

29. NR. Faria, J. Quick, I. Morales I, J. Thézé, JG. Jesus et al, Nature, 546,7658, 406-410 (2017)

30. T. Charalampous, GL. Kay, H. Richardson, A. Aydin, R. Baldan, C. Jeanes, D. Rae, S. Grundy, DJ. Turner, J. Wain, RM. Leggett, DM. Livermore, J. O'Grady, Nature biotechnology, 37,7, 783-792 (2019)

31. Y. Xu, K. Lewandowski, K. Jeffery, LO. Downs, D. Foster, ND. Sanderson, J. Kavanagh, A. Vaughan, C. Salvagno, R. Vipond, M. Carroll, R. Danby, T. Peto, D. Crook, AS. Walker, PC. Matthews, ST. Pullan, The Journal of infection, 80,5, 571-577 (2020)

32. K. Lewandowski, Y. Xu, ST. Pullan, SF. Lumley, D. Foster, N. Sanderson, A. Vaughan, M. Morgan, N. Bright, J. Kavanagh, R. Vipond, M. Carroll, AC. Marriott, KE. Gooch, M. Andersson, K. Jeffery, TEA. Peto, DW. Crook, AS. Walker, PC. Matthews, Journal of clinical microbiology, 58,1 e00963-19, (2019)

33. R. Lu, X. Zhao, J. Li, P. Niu, B. Yang, H. Wu, W. Wang, H. Song, B. Huang, N. Zhu, Y. Bi, X. Ma, F. Zhan, L. Wang, T. Hu, H. Zhou, Z. Hu, W. Zhou, L. Zhao, J. Chen, Y. Meng, J. Wang, Y. Lin, J. Yuan, Z. Xie, J. Ma, WJ. Liu, D. Wang, W. Xu, EC. Holmes, GF. Gao, G. Wu, W. Chen, W. Shi, W. Tan, Lancet (London, England), 395,10224, 565-574 (2020)

34. ML. Holshue, C. DeBolt, S. Lindquist, KH. Lofy, J. Wiesman, H. Bruce, C. Spitters, K. Ericson, S. Wilkerson, A. Tural, G. Diaz, A. Cohn, L. Fox, A. Patel, SI. Gerber, L. Kim, S. Tong, X. Lu, S. Lindstrom, MA. Pallansch, WC. Weldon, HM. Biggs, TM. Uyeki, SK. Pillai, The New England journal of medicine, 382,10, 929-936 (2020) 
35. JG. Jesus, C. Sacchi, DDS. Candido, IM. Claro, FCS. Sales, ER. Manuli, D. Silva, TM. Paiva, MAB. Pinho, KCO. Santos, SC. Hill, RS. Aguiar et al, Revista do Instituto de Medicina Tropical de Sao Paulo, 62, e30 (2020)

36. D. Kim, JY. Lee, JS. Yang, JW. Kim, VN. Kim, H. Chang, Cell, 181,4, 914-921, e10 (2020)

37. CL. Liao, M. Lai, Journal of virology, 66,10, 6117-24 (1992)

38. N. Moldován, Z. Balázs, D. Tombácz, Z. Csabai, A. Szűcs, M. Snyder, Z. Boldogkői, Virus research, 237, 37-46 (2017)

39. SM. Karst, MS. Dueholm, SJ. McIlroy, RH. Kirkegaard, PH. Nielsen, M. Albertsen, Nature biotechnology, 36,2, 190-195 (2018)

40. DP. Depledge, KP.Srinivas, T. Sadaoka, D. Bready, Y. Mori, DG. Placantonakis, I Mohr, AC. Wilso n, Nature communications, 10,1 754 (2019)

41. DR. Garalde, EA. Snell, D. Jachimowicz, B. Sipos, JH. Lloyd, M. Bruce, N. Pantic, T. Admassu, P. James, A. Warland, M. Jordan, J. Ciccone, S. Serra, J. Keenan, S. Martin, L. McNeill, EJ. Wallace, L. Jayasinghe, C. Wright, J. Blasco, S. Young, D. Brocklebank, S. Juul, J. Clarke J, AJ. Heron, DJ. Turner, Nature methods, 15,3, 201-206 (2018)

42. J. Quick, ND. Grubaugh, ST. Pullan, IM. Claro, AD. Smith, K. Gangavarapu K, G. Oliveira, R. Robles-Sikisaka, TF. Rogers, NA. Beutler, DR. Burton et al, Nature protocols, 12,6, 1261-1276 (2017)

43. J. Harcourt, A. Tamin, X. Lu, S. Kamili, SK. Sakthivel, J. Murray, K. Queen, Y. Tao, CR. Paden, J. Zhang, Y. Li, A. Uehara, H. Wang, C. Goldsmith et al, Emerging infectious diseases, 26,6, 1266-1273 (2020)

44. JF. Chan, S. Yuan, KH. Kok, KK. To, H. Chu, J. Yang, F. Xing, J. Liu, CC. Yip, RW. Poon, HW. Tsoi, Lo. SK, KH. Chan, VK. Poon, WM. Chan, JD. Ip, JP. Cai, VC. Cheng, H. Chen, CK. Hui, KY. Yuen, Lancet (London, England), 395,10223, 514-523 (2020)

45. SCB. Stubbs, BA. Blacklaws, B. Yohan, FA. Yudhaputri, RF. Hayati, B. Schwem, EM. Salvaña, RV. Destura, JS. Lester, KS. Myint, RT. Sasmono RT, SDW. Frost, Virol J, 17, 24 (2020)

46. A. Kilianski, JL. Haas, EJ. Corriveau, AT. Liem, KL. Willis, DR. Kadavy, CN. Rosenzweig, SS. Minot, GigaScience, 4, 12 (2015)

47. A. Benítez-Páez, Y. Sanz, GigaScience, 6,7, 1-12 (2017)

48. ONT,https://nanoporetech.com/sites/default/files/s3/literature/product-brochure.pdf (Accessed: December, 2020). 